\title{
Independent risk factors and long-term outcomes for acute kidney injury in pediatric patients undergoing hematopoietic stem cell transplantation: a retrospective cohort study
}

Daishi Hirano ${ }^{1 *}$ (D), Daisuke Kakegawa', Saori Miwa ${ }^{1}$, Chisato Umeda ${ }^{1,2}$, Yoichi Takemasa', Ai Tokunaga', Yuhei Kawakami ${ }^{1}$ and Akira Ito ${ }^{1}$

\begin{abstract}
Background: Acute kidney injury (AKI) remains a frequent complication in children undergoing hematopoietic stem cell transplantation (HSCT) and an independent risk factor of the patient's survival and a prognostic factor of progression to chronic kidney disease (CKD). However, the causes of these complications are diverse, usually overlapping, and less well understood.

Methods: This retrospective analysis was performed in 43 patients (28 boys, 15 girls; median age, 5.5 years) undergoing HSCT between April 2006 and March 2019. The main outcome was the development of AKI defined according to the Pediatric Risk, Injury, Failure, Loss, End-stage Renal Disease (pRIFLE) criteria as $\geq 25 \%$ decrease in estimated creatinine clearance. The secondary outcome was the development of CKD after a 2-year follow-up.
\end{abstract}

Results: AKI developed in 21 patients (49\%) within 100 days after HSCT. After adjusting for possible confounders, posttransplant AKI was associated with matched unrelated donor (MUD) (HR, 6.26; $P=0.042)$, but not total body irradiation (TBI). Of 37 patients who were able to follow-up for 2 years, 7 patients died, but none had reached CKD during the 2 years after transplantation.

Conclusions: Posttransplant AKI was strongly associated with HSCT from MUD. Although the incidence of AKI was high in our cohort, that of posttransplant CKD was lower than reported previously in adults. TBI dose reduced, GVHD minimized, and infection prevented are required to avoid late renal dysfunction after HSCT in children since their combinations may contribute to the occurrence of AKI.

Keywords: Acute kidney injury, Matched unrelated donor, pRIFLE, Child, Risk factor

\footnotetext{
* Correspondence: bqx1976@hotmail.com

'Department of Pediatrics, The Jikei University School of Medicine, 3-25-8

Nishi-Shimbashi, Minato-ku, Tokyo 105-0003, Japan

Full list of author information is available at the end of the article
}

(c) The Author(s). 2020 Open Access This article is licensed under a Creative Commons Attribution 4.0 International License, which permits use, sharing, adaptation, distribution and reproduction in any medium or format, as long as you give appropriate credit to the original author(s) and the source, provide a link to the Creative Commons licence, and indicate if changes were made. The images or other third party material in this article are included in the article's Creative Commons licence, unless indicated otherwise in a credit line to the material. If material is not included in the article's Creative Commons licence and your intended use is not permitted by statutory regulation or exceeds the permitted use, you will need to obtain permission directly from the copyright holder. To view a copy of this licence, visit http://creativecommons.org/licenses/by/4.0/ The Creative Commons Public Domain Dedication waiver (http://creativecommons.org/publicdomain/zero/1.0/) applies to the data made available in this article, unless otherwise stated in a credit line to the data. 


\section{Background}

The risks of chronic kidney disease (CKD), as well as short- and long-term mortality rates, are increased in patients who develop acute kidney injury (AKI) following hematopoietic stem cell transplantation (HSCT). AKI continues to show adverse health effects after hospital discharge, and the risks of CKD and long-term mortality were reported to be greater in patients with than without AKI [1]. AKI was reported to occur in 20 to $84 \%$ of pediatric patients undergoing HSCT [2-4]. AKI after HSCT has multifactorial etiologies with prerenal, renal, and postrenal mechanisms, including conditioning chemotherapy, total body irradiation (TBI), nephrotoxic medications, sepsis, sinusoidal obstruction syndrome (SOS), thrombotic microangiopathy (TMA), and graft-versus-host disease (GVHD) [5-7]. With advances in supportive care, the prevalence of post-HSCT AKI had decreased over the past several years [8-12]. However, kidney injury remains a significant complication of HSCT, negatively affecting patients' quality of life (QOL) and both early and long-term mortality rates. Therefore, to improve transplant outcomes, it is important to determine risk factors, understand the causes, and develop methods for the early diagnosis and treatment of kidney injury.

It was difficult to determine the epidemiology of pediatric HSCT-related AKI as previous studies used various definitions of AKI. Therefore, it is necessary to develop a consistent, uniform definition to gain insight into the epidemiology of pediatric AKI and to facilitate comparisons between different studies, which would lead to improvements in prognosis. The Pediatric Risk, Injury, Failure, Loss, End-stage Renal Disease (pRIFLE) criteria were developed in 2007 to address this issue [13]. Accurate determination of the incidence, risk factors, and prognosis of pediatric HSCT-related AKI will require the accumulation of studies based on these standardized criteria. Therefore, the present study was performed to examine the incidence of AKI after HSCT defined according to the pRIFLE criteria, to identify independent risk factors for the development of AKI, and to examine the association between AKI and progression to CKD to identify factors that contribute to AKI.

\section{Materials and methods}

\section{Study population}

This study was performed using data for all children undergoing HSCT between April 2006 and March 2019 at Jikei University School of Medicine, Japan, including information on age at disease onset, sex, comorbidities, age at transplantation, transplant characteristics (e.g., type of donor, graft source, HLA matching, method of GVHD prophylaxis), indications for HSCT, conditioning regimen, acute GVHD, sinusoidal obstruction syndrome (SOS), transplant-associated thrombotic microangiopathy (TMA), tumor lysis syndrome (TLS), nephrotoxic medication exposure, renal replacement therapy (RRT), AKI, and survival outcome. The exclusion criteria were age $>21$ years old, history of prior dialysis, and missing pre- or post-HSCT height, body weight, and serum creatinine $(\mathrm{sCr})$ values. Only the first HSCT was counted for patients that underwent more than one transplant during the study period.

\section{Outcome variables}

The cumulative incidence and severity of AKI within 100 days after HSCT were taken as the primary endpoints in this study. In accordance with the pRIFLE criteria, AKI was defined as a decrease in the estimated glomerular filtration rate $(\mathrm{eGFR}) \geq 25 \%$ [13]. Uemura's equation was used to calculate sCr-based eGFR [14]. The baseline $\mathrm{sCr}$ was defined as the median of three extracted $\mathrm{sCr}$ levels measured during the four weeks before the conditioning regimen. As all urine output data were not available, pRIFLE class was determined based on the worst $\mathrm{sCr}$ level. To evaluate the effects of AKI severity on outcome, the maximum stage of AKI was defined as the highest stage observed within the first 100 days after HSCT. The secondary outcome was the development of CKD after a 2-year follow-up. According to the National Kidney Foundation-Kidney Disease Outcomes Quality Initiative guideline, CKD was defined as an eGFR $<90$ $\mathrm{mL} / \mathrm{min} / 1.73 \mathrm{~m}^{2}$ being persistent more than 3 months post-transplant [15]. Acute GVHD was graded according to the standard criteria [16]. The diagnosis and severity of SOS were defined according to the modified Seattle criteria [17]. Both acute GVHD and SOS were considered valid only if they developed before AKI and were included in our analysis to evaluate their effects on AKI.

\section{Statistical analysis}

Patient and disease characteristics were summarized using descriptive statistics. Categorical variables were reported as frequencies and percentages and were compared using the chi-square test or Fisher's exact test as appropriate. Continuous variables were reported as the median (interquartile range; IQR) and were compared using the Mann-Whitney $U$ test. Survival data were analyzed using the Kaplan-Meier method and were compared across groups using the log-rank test [18, 19]. Multivariable analysis using the Cox proportional hazards model was performed to identify independent risk factors for the occurrence of AKI, and to adjust for variables such as sex, age at HSCT, donor source, TBI, and GVHD, predictors of AKI identified in previous studies including statistically significant variables on univariate 
analysis. In the Cox regression models, follow-up time was counted from the date of HSCT until the date on which the outcome was reached or the date of the last examination. All statistical analyses were performed using STATA 14.2 (StataCorp, College Station, TX). In all analyses, $P<0.05$ was taken to indicate statistical significance.

\section{Results}

\section{Baseline characteristics of the study population and prevalence of AKI}

A total of 50 children underwent HSCT during the study period at our institute, and 43 of these children fulfilled the inclusion criteria. Data regarding 2-year outcomes were available for 37 of the 43 total patients (Fig. 1). Table 1 summarize the patient characteristics. Fortythree of 50 children undergoing HSCT at our institute during the study period met the inclusion criteria for this study. The median age of the study population at the time of HSCT was 5.5 years (IQR, 4.1-10.8), and $65 \%$ were boys. Stem cells for transplantation were obtained from bone marrow $(n=19,44 \%)$, peripheral blood ( $n=21,49 \%)$, or cord blood $(n=3,7 \%)$, and were from autologous ( $n=20,46 \%)$, matched related donor (MRD), $(n=5,12 \%)$, and matched unrelated donor (MUD) $(n=$ $18,42 \%)$ as the source. Twenty-one patients (49\%) developed AKI within the first 100 days after HSCT, and the median time between transplantation and AKI was 38.0 days (IQR, 26.0-63.0). Using the pRIFLE criteria, 12 (28\%) patients were at risk of renal dysfunction, 5 (12\%) patients had injury to the kidney, and 4 (9\%) had failure of kidney function. Two cases (5\%) in the total cohort underwent postoperative dialysis.

\section{Factors associated with the development of AKI}

On univariate analysis, the development of AKI after HSCT was significantly associated with TBI and MUD $(P<0.01, P<0.01$, respectively). There were no significant differences in age at the time of transplant, sex, indication for HSCT, use of calcineurin inhibitors, or presence of aGVHD between patients with and without AKI. On Kaplan-Meier survival analysis, the cumulative incidence of AKI was higher in patients with TBI or MUD than in those without TBI or MUD $(P=0.012$, $P<0.01$, respectively) (Fig. 2a, b). After adjustment for possible confounding factors, posttransplant AKI was associated with MUD $(P=0.042)$, but not with TBI use (Table 2).

\section{Two-year outcomes of patients with Posttransplant AKI}

Data regarding 2-year outcomes were available for 37 of the 43 total patients. Seven patients (19\%) in the total study population died during the 2-year follow-up period due to progression of primary disease $(n=5)$, infection $(n=1)$, and end-stage renal disease $(n=1)$. None of the children who survived had chronic renal insufficiency 2 years after HSCT. The groups with and without AKI showed 2-year overall survival (OS) rates of 81 and $86 \%$, respectively, which were not significantly different $(P=$ $0.70)$.

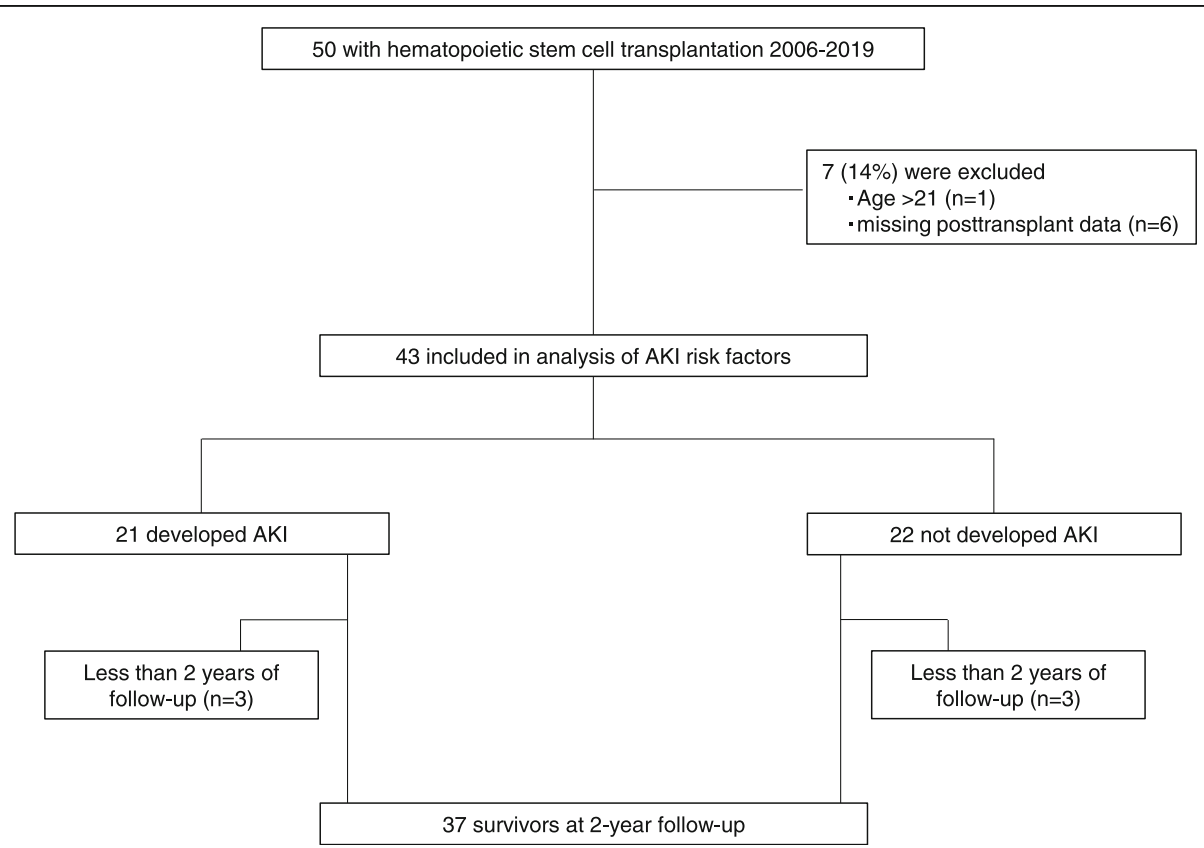

Fig. 1 Study population. A total of 50 children underwent HSCT during the study period. Of these, 43 children fulfilled the inclusion criteria. Data regarding 2-year outcome were available for 37 patients 
Table 1 Patient characteristics

\begin{tabular}{|c|c|c|c|c|}
\hline & Whole cohort $(\boldsymbol{n}=43)$ & $\operatorname{AKI}(\boldsymbol{n}=21)$ & Non-AKI $(\boldsymbol{n}=22)$ & $\boldsymbol{P}$-value \\
\hline Age at HSCT, years, median (IQR) & $5.5(4.1-10.8)$ & $5.5(4.2-14.4)$ & $5.2(4.1-7.8)$ & 0.37 \\
\hline Sex, Male, $n(\%)$ & $28(65)$ & $14(67)$ & $14(64)$ & 0.84 \\
\hline \multicolumn{5}{|l|}{ Indication for HSCT } \\
\hline Malignant & $34(79)$ & $18(86)$ & $16(73)$ & 0.46 \\
\hline \multicolumn{5}{|l|}{ Conditioning regimen, $n$ (\%) } \\
\hline Calcineurin inhibitor & $4(9)$ & $2(10)$ & $2(9)$ & 1.00 \\
\hline TBI use & $22(51)$ & $15(71)$ & $7(32)$ & $<0.01$ \\
\hline \multicolumn{5}{|l|}{ Stem cell source, $n$ (\%) } \\
\hline Bone marrow & $19(44)$ & $9(43)$ & $10(45)$ & 0.86 \\
\hline Peripheral blood & $21(49)$ & $9(43)$ & $12(55)$ & 0.44 \\
\hline Umbilical cord & $3(7)$ & $3(14)$ & $0(0)$ & 0.11 \\
\hline \multicolumn{5}{|l|}{ Donor source, $n$ (\%) } \\
\hline Autologous & $20(46)$ & $7(33)$ & $13(59)$ & 0.091 \\
\hline MRD & $5(12)$ & $1(5)$ & $4(18)$ & 0.35 \\
\hline MUD & $18(42)$ & $13(62)$ & $5(23)$ & $<0.01$ \\
\hline Acute GVHD, $n(\%)$ & $20(47)$ & $12(67)$ & $8(36)$ & 0.17 \\
\hline 1 & $8(19)$ & $4(18)$ & $4(18)$ & 1.00 \\
\hline$\|-I V$ & $12(28)$ & $8(38)$ & $4(19)$ & 0.19 \\
\hline
\end{tabular}

HSCT, hematopoietic stem cell transplantation; TBI, total body irradiation; MRD, matched related donor; MUD, matched unrelated donor; GVHD, graft-versus-host disease

\section{Discussion}

The present observational study was performed to investigate the incidence of AKI defined according to the pRIFLE criteria following HSCT in pediatric patients. We also identified independent risk factors for the development of AKI and evaluated the associated risk of CKD in this clinical setting.

AKI occurred within 100 days of transplantation at a rate of $49 \%$ in this study population. Thus, AKI appears to be common in pediatric HSCT recipients. Moreover, we also found that the occurrence of various degrees of AKI spread after HSCT. The reported incidence rate of AKI after HSCT in pediatric patients shows a wide range of $21-84 \%$ due primarily to the use of different definitions of AKI and also the large degree of heterogeneity in patient characteristics $[3,9,20-22]$. The pRIFLE criteria were used in the present study, which allowed a fuller understanding of the epidemiology of pediatric AKI. As the pRIFLE criteria can detect renal dysfunction in the early stages, which detection of AKI at a high rate of $49 \%$ in the present study, similar to previous reports [3, 23].

Several risk factors for AKI in patients undergoing HSCT have been reported. The descriptions of transplant characteristics, such as donor, race, TBI, nephrotoxic agents, and post-transplant adverse events, such as SOS and VOD, were inconsistently described as risk factors for the development of AKI in pediatric patients [3,
11, 20-25]. After adjusting for possible confounding variables by logistic regression analysis, HSCT from unrelated donors was shown to be an independent risk factor for posttransplant AKI in the present study, whereas sex, age, TBI, and acute GVHD were not related to the incidence of AKI. Unrelated donor HSCT was reported previously to be related to significant increases in the risk of infections, severe aGVHD, and organ toxicities [2631]. Although these complications may not represent independent risk factors for AKI, their combinations may contribute to the occurrence of AKI. In addition, the nephrotoxic agents used in the treatment of these complications can also lead to AKI.

In contrast to previous studies in adult patients, chronic renal insufficiency 2 years after HSCT was not correlated with AKI in our cohort. None of the pediatric patients included in the present study had chronic renal insufficiency 2 years after HSCT, despite the high frequency of AKI. The cumulative incidence rate of CKD in adult patients after HSCT was reported to vary from 13 to $66 \%$ [32-35]. Similar to our findings, other studies reported CKD prevalence rates of $8-11 \%$ per year in pediatric patients [3, 21, 22]. Risk factors for posttransplant CKD include previous AKI, acute and chronic GVHD, age $\geq 45$ years at the time of transplantation, baseline eGFR $<90 \mathrm{ml} / \mathrm{min} / 1.73 \mathrm{~m}^{2}$, hypertension, and exposure to high-dose TBI [22, 36-39]. Although TBI has been suggested to induce artery and capillary 

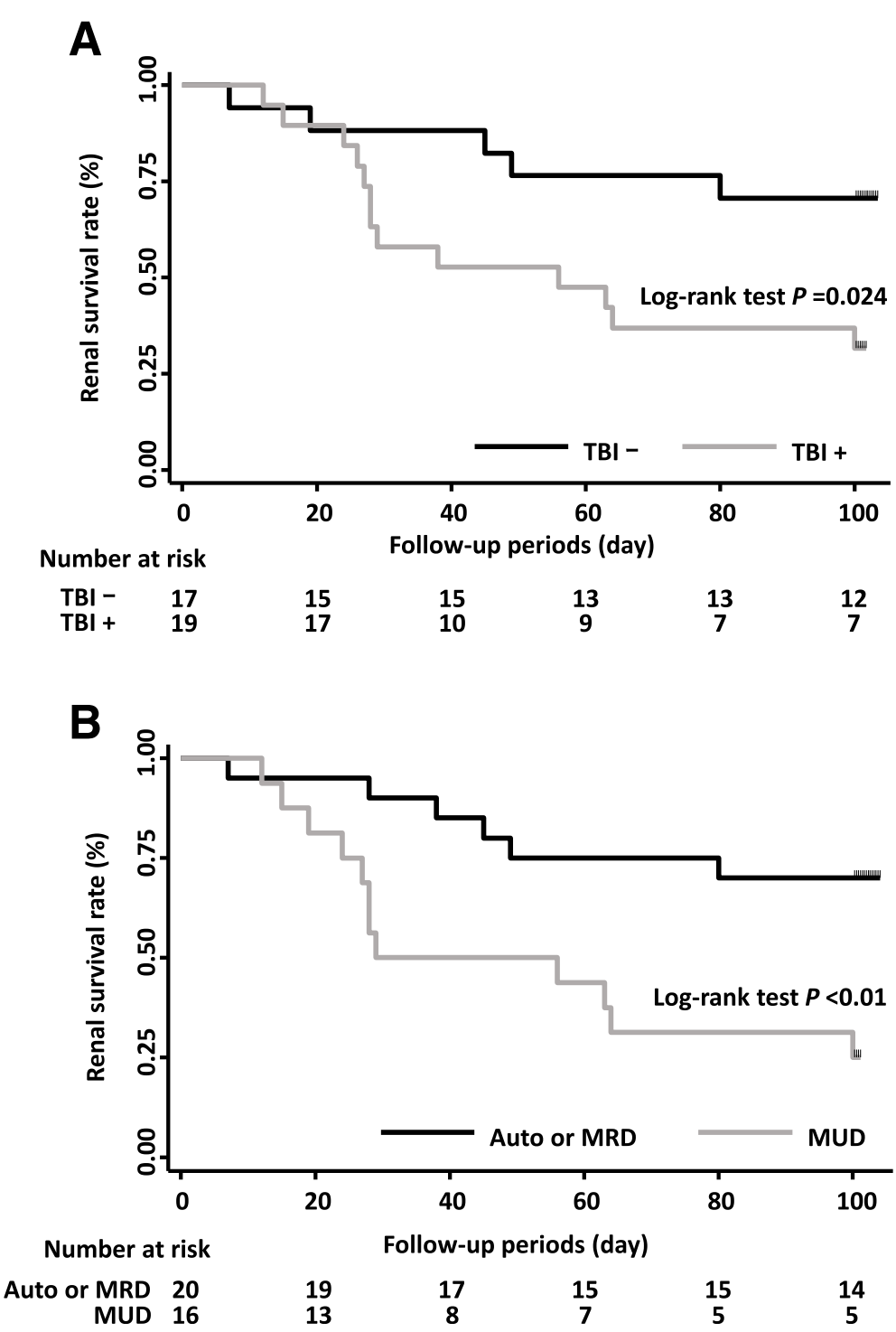

Fig. 2 AKI development probability graph according to the survival analysis and log-rank test. AKI development probabilities were higher in patients with than in those without TBI or MUD (Fig. 2a, Fig. 2b, respectively)

Table 2 Cox hazard regression analysis of possible risk factors for posttransplant AKI

\begin{tabular}{lllll}
\hline & \multicolumn{4}{l}{$95 \%$ confidence interval $(\mathrm{Cl})$} \\
\cline { 2 - 5 } & Hazard ratio & Lower & Upper & $\boldsymbol{P}$-value \\
\hline Sex (male) & 1.11 & 0.43 & 2.82 & 0.83 \\
Age (> 10 years) & 0.96 & 0.38 & 2.45 & 0.93 \\
Donor source (MUD) & 6.26 & 1.07 & 36.76 & 0.042 \\
TBI use & 2.18 & 0.63 & 7.60 & 0.22 \\
Acute GVHD & 0.25 & 0.05 & 1.24 & 0.09 \\
\hline
\end{tabular}

MUD, matched unrelated donor; TBI, total body irradiation; GVHD, graft-versus-host disease sclerosis, interstitial fibrosis, and to play a major role in renal damage [40-44], Kal et al. [45] reported that late renal dysfunction can be avoided by reducing the strength of the TBI regimen to $<16$ Gy and by using appropriate kidney shielding. Since the development of a reduced-intensity TBI regimen (<10 Gy), TBI was not an etiological pathogenetic factor in the present study in contrast to previous reports showing dose-dependent toxicity, even in pediatric patients $[36,46]$. In addition, the favorable outcome in the present study may also have been related to recent progress in supportive care, management of GVHD, and HLA typing techniques.

This study had several limitations, the first of which is related to its retrospective nature in pediatric patients undergoing HSCT at a single center, which may have 
resulted in a degree of selection bias. The single-center cohort design also limited the external validity of our findings. Besides, since we were not able to obtain data about previously well-known risk factors such as prior AKI, severe infection, nephrotoxic antibiotics or antifungal agents, and contrast dye for computed tomography, we could not conduct more in-depth analyses for identifying risk factors predicting AKI. Second, as previously shown by Kaddourah A et al., decreased urine output without a significant change in $\mathrm{sCr}$ is a massive determinant of AKI in critically ill children [47]. Therefore, AKI was possibly underestimated in this study, since we could not obtain the data of urine output. In addition, the accuracy and validity of this work are further limited by the use of the "worst sCr level" because such level could have been abnormally related to prior interventions that were part of the delivered care that resulted in the need for HSCT. Third, the follow-up period of 2 years in this study was too short to allow documentation of all outcomes. However, in most studies reported to date, $70 \%$ of cases of CKD occurred within 2 years (especially within 6 months), and the incidence of CKD $>2$ years after transplantation is relatively rare [48, 49]. Fourth, low statistical power and model overfitting may have been existent due to the limited sample size.

\section{Conclusion}

The results presented here indicated that the occurrence of posttransplant AKI was strongly associated with HSCT from unrelated donors. Despite the high rate of posttransplant AKI, the rate of posttransplant CKD was lower than in previous studies in adult patients. The dose of TBI should be reduced, and kidney shielding should be applied to avoid the occurrence of late renal dysfunction after HSCT.

\section{Acknowledgements}

The authors would like to thank Drs. Masaharu Akiyama of the Division of Pediatric Hematology and Oncology, the Jikei University School of Medicine. The results presented in this paper have not been published previously in whole or part except in abstract form.

\section{Authors' contributions}

D.H. and A.I. conceptualized and designed the study, drafted the initial manuscript, and reviewed and revised the manuscript. D.K. and S.M. collected clinical data. C.U., Y.T., A.T., and Y.K. reviewed clinical data and fixed outcomes as members of the endpoint committee. D.H. analysed data statistically and wrote the first draft of the manuscript. All authors have seen and approved the final manuscript.

\section{Funding}

This research received no specific grant from any funding agency in the public, commercial, or not-for-profit sections.

\section{Availability of data and materials}

The datasets used and analyzed during the current study are available from the corresponding author.

\section{Ethics approval and consent to participate}

This study was conducted in accordance with the ethical principles of the Declaration of Helsinki and with the Ethical Guidelines for Epidemiological Research issued by the Ministry of Health, Labour, and Welfare of Japan. The study was approved by the Ethics Review Committee of Jikei University School of Medicine (ID: 9573). As the data were obtained retrospectively from patient charts, informed consent was deemed unnecessary following the above guidelines.

\section{Consent for publication}

Not applicable.

\section{Competing interests}

The authors declare no competing financial interests.

\section{Author details}

${ }^{1}$ Department of Pediatrics, The Jikei University School of Medicine, 3-25-8 Nishi-Shimbashi, Minato-ku, Tokyo 105-0003, Japan. ²Division of Nephrology, Saitama Children's Medical Center, Saitama, Japan.

Received: 1 June 2020 Accepted: 23 August 2020

Published online: 27 August 2020

\section{References}

1. Parikh CR, Schrier RW, Storer B, Diaconescu R, Sorror ML, Maris MB, et al. Comparison of ARF after myeloablative and nonmyeloablative hematopoietic cell transplantation. Am J Kidney Dis. 2005;45:502-9.

2. Raina R, Herrera N, Krishnappa V, Sethi SK, Deep A, Kao WM, et al. Hematopoietic stem cell transplantation and acute kidney injury in children: A comprehensive review. Pediatr Transplant 2017: 21: petr.12935.

3. Kizilbash SJ, Kashtan CE, Chavers BM, Cao Q, Smith AR. Acute kidney injury and the risk of mortality in children undergoing hematopoietic stem cell transplantation. Biol Blood Marrow Transplant. 2016;22:1264-70.

4. Lopes JA, Jorge S, Neves M. Acute kidney injury in HCT: an update. Bone Marrow Transplant. 2016;51:755-62.

5. Wan L, Bagshaw SM, Langenberg C, Saotome T, May C, Bellomo R. Pathophysiology of septic acute kidney injury: what do we really know? Crit Care Med. 2008;36(4 Suppl):S193-203.

6. Keating GM. Defibrotide. A review of its use in severe hepatic venoocclusive disease following haematopoietic stem cell transplantation. Clin Drug Investig. 2014:34:895-904.

7. Parikh CR, Coca SG. Acute renal failure in hematopoietic cell transplantation. Kidney Int. 2006:69:430-5.

8. Gooley TA, Chien JW, Pergam SA, Hingorani S, Sorror ML, Boeckh M, et al. Reduced mortality after allogeneic hematopoietic-cell transplantation. N Engl J Med. 2010;363:2091-101.

9. Hingorani S. Renal complications of hematopoietic-cell transplantation. N Engl J Med. 2016;374:2256-67.

10. Canet E, Lengline E, Zafrani L, Peraldi MN, Socié G, Azoulay E. Acute kidney injury in critically ill Allo-HSCT recipients. Bone Marrow Transplant. 2014;49: 1121-2.

11. Didsbury MS, Mackie FE, Kennedy SE. A systematic review of acute kidney injury in pediatric allogeneic hematopoietic stem cell recipients. Pediatr Transplant. 2015:19:460-70.

12. Kersting $\mathrm{S}$, Koomans HA, Hené RJ, Verdonck LF. Acute renal failure after allogeneic myeloablative stem cell transplantation: retrospective analysis of incidence, risk factors and survival. Bone Marrow Transplant. 2007;39:359-65.

13. Akcan-Arikan A, Zappitelli M, Loftis LL, Washburn KK, Jefferson LS, Goldstein SL. Modified RIFLE criteria in critically ill children with acute kidney injury. Biol Kidney Int. 2007;71:1028-35.

14. Uemura O, Honda M, Matsuyama T, Ishikura K, Hataya H, Yata N, et al. Age, gender, and body length effects on reference serum creatinine levels determined by an enzymatic method in Japanese children: a multicenter study. Clin Exp Nephrol. 2011;15:694-9.

15. Inker LA, Astor BC, Fox CH, Isakova T, Lash JP, Peralta CA, et al. KDOQI US commentary on the 2012 KDIGO clinical practice guideline for the evaluation and management of CKD. Am J Kidney Dis. 2014;63:713-35.

16. Przepiorka D, Weisdorf D, Martin P, Klingemann HG, Beatty $P$, Hows J, et al. 1994 consensus conference on acute GVHD grading. Bone Marrow Transplant. 1995;15:825-8. 
17. McDonald GB, Hinds MS, Fisher LD, Schoch HG, Wolford $J L$, Banaji M, et al. Veno-occlusive disease of the liver and multiorgan failure after bone marrow transplantation: a cohort study of 355 patients. Ann Intern Med. 1993;118:255-67.

18. Klein JP, Rizzo JD, Zhang MJ, Keiding N. Statistical methods for the analysis and presentation of the results of bone marrow transplants. Part I: unadjusted analysis. Bone Marrow Transplant. 2001;28:909-15.

19. Klein JP, Rizzo JD, Zhang MJ, Keiding N. Statistical methods for the analysis and presentation of the results of bone marrow transplants. Part 2: regression modeling. Bone Marrow Transplant. 2001;28:1001-11.

20. Hazar V, Gungor O, Guven AG, Aydin F, Akbas H, Gungor F, et al. Renal function after hematopoietic stem cell transplantation in children. Pediatr Blood Cancer. 2009;53:197-202.

21. Kist-van Holthe JE, Goedvolk CA, Brand R, van Weel MH, Bredius RG, van Oostayen JA, et al. Prospective study of renal insufficiency after bone marrow transplantation. Pediatr Nephrol. 2002;17:1032-7.

22. Ileri T, Ertem M, Ozcakar ZB, Ince EU, Biyikli Z, Uysal Z, et al. Prospective evaluation of acute and chronic renal function in children following matched related donor hematopoietic stem cell transplantation. Pediatr Transplant. 2010;14:138-44.

23. Koh KN, Sunkara A, Kang G, Sooter A, Mulrooney DA, Triplett B, et al. Acute kidney injury in pediatric patients receiving allogeneic hematopoietic cell transplantation: incidence, risk factors, and outcomes. Biol Blood Marrow Transplant. 2018;24:758-64.

24. Kist-van Holthe JE, van Zwet JM, Brand R, van Weel MH, Vossen JM, van der Heijden AJ. Bone marrow transplantation in children: consequences for renal function shortly after and 1 year post-BMT. Bone Marrow Transplant. 1998;22:559-64.

25. Lopes JA, Jorge S. Acute kidney injury following HCT: incidence, risk factors and outcome. Bone Marrow Transplant. 2011;46:1399-408.

26. Li JM, Giver CR, Lu Y, Hossain MS, Akhtari M, Waller EK. Separating graftversus-leukemia from graft-versus-host disease in allogeneic hematopoietic stem cell transplantation. Immunotherapy. 2009;1:599-621.

27. Laughlin MJ, Eapen M, Rubinstein P, Wagner JE, Zhang MJ, Champlin RE, et al. Outcomes after transplantation of cord blood or bone marrow from unrelated donors in adults with leukemia. N Engl J Med. 2004;351:2265-75.

28. Shaw PJ, Kan F, Woo Ahn K, Spellman SR, Aljurf M, Ayas M, et al. Outcomes of pediatric bone marrow transplantation for leukemia and myelodysplasia using matched sibling, mismatched related, or matched unrelated donors. Blood. 2010;116:4007-15.

29. Koh KN, Park M, Kim BE, Bae KW, Im HJ, Seo JJ. Favorable outcomes after allogeneic hematopoietic stem cell transplantation in children with high-risk or advanced acute myeloid leukemia. J Pediatr Hematol Oncol. 2011;33: 281-8.

30. Mogul MJ. Unrelated cord blood transplantation vs matched unrelated donor bone marrow transplantation: the risks and benefits of each choice. Bone Marrow Transplant 2000; Suppl 2: S58-60.

31. Parody R, Martino R, Rovira M, Vazquez L, Vázquez MJ, de la Cámara R, et al. Infectious/non-infectious complications Subcommittee of the Grupo Español de Trasplante Hematopoyético (GETH) severe infections after unrelated donor allogeneic hematopoietic stem cell transplantation in adults: comparison of cord blood transplantation with peripheral blood and bone marrow transplantation. Biol Blood Marrow Transplant. 2006;12:73448.

32. Mehta RL, Kellum JA, Shah SV, Molitoris BA, Ronco C, Warnock DG, et al. Acute kidney injury network: report of an initiative to improve outcomes in acute kidney injury. Crit Care. 2007;11:R31.

33. Ellis MJ, Parikh CR, Inrig JK, Kanbay M, Patel UD. Chronic kidney disease after hematopoietic cell transplantation: a systematic review. Am J Transplant. 2008;8:2378-90

34. Abboud I, Peraldi MN, Hingorani S. Chronic kidney diseases in long-term survivors after allogeneic hematopoietic stem cell transplantation: monitoring and management guidelines. Semin Hematol. 2012;49:73-82.

35. Hingorani S. Chronic kidney disease in long-term survivors of hematopoietic cell transplantation: epidemiology, pathogenesis, and treatment. J Am Soc Nephrol. 2006;17:1995-2005.

36. Abboud I, Porcher R, Robin M, de Latour RP, Glotz D, Socié G, et al. Chronic kidney dysfunction in patients alive without relapse 2 years after allogeneic hematopoietic stem cell transplantation. Biol Blood Marrow Transplant. 2009:15:1251-7.
37. Glezerman IG, Jhaveri KD, Watson TH, Edwards AM, Papadopoulos EB, Young JW, et al. Chronic kidney disease, thrombotic microangiopathy, and hypertension following T cell-depleted hematopoietic stem cell transplantation. Biol Blood Marrow Transplant. 2010;16:976-84.

38. Sakellari I, Barbouti A, Bamichas G, Mallouri D, Kaloyannidis P, Fragidis S, et al. GVHD-associated chronic kidney disease after allogeneic haematopoietic cell transplantation. Bone Marrow Transplant. 2013;48:1329_ 34.

39. Ando M, Ohashi K, Akiyama H, Sakamaki H, Morito T, Tsuchiya K, et al. Chronic kidney disease in long-term survivors of myeloablative allogeneic haematopoietic cell transplantation: prevalence and risk factors. Nephrol Dial Transplant. 2010;25:278-82.

40. Cohen EP. Radiation nephropathy after bone marrow transplantation. Kidney Int. 2000;58:903-18.

41. Lönnerholm G, Carlson K, Bratteby LE, Bäcklund L, Hagberg H, Rikner G, et al. Renal function after autologous bone marrow transplantation. Bone Marrow Transplant. 1991;8:129-34.

42. Molteni A, Moulder JE, Cohen EP, Fish BL, Taylor JM, Veno PA, et al. Prevention of radiation-induced nephropathy and fibrosis in a model of bone marrow transplant by an angiotensin II receptor blocker. Exp Biol Med (Maywood). 2001;226:1016-23.

43. Leblond V, Sutton L, Jacquiaud C, Item C, Sadoun R, Jaudon MC, et al. Evaluation of renal function in 60 long-term survivors of bone marrow transplantation. J Am Soc Nephrol. 1995;6:1661-5.

44. Frisk P, Bratteby LE, Carlson K, Lönnerholm G. Renal function after autologous bone marrow transplantation in children: a long-term prospective study. Bone Marrow Transplant. 2002;29:129-36.

45. Kal HB, van Kempen-Harteveld ML. Renal dysfunction after total body irradiation: dose-effect relationship. Int J Radiat Oncol Biol Phys. 2006;65: 1228-31.

46. Miralbell R, Bieri S, Mermillod B, Helg C, Sancho G, Pastoors B, et al. Renal toxicity after allogeneic bone marrow transplantation: the combined effects of total-body irradiation and graft-versus-host disease. J Clin Oncol. 1996;14: 579-85

47. Kaddourah A, Basu RK, Bagshaw SM, Goldstein SL, Investigators AWARE. Epidemiology of acute kidney injury in critically ill children and Young adults. N Engl J Med. 2017;376:11-20.

48. Jo T, Arai Y, Kondo T, Kitano T, Hishizawa M, Yamashita K, et al. Chronic kidney disease in long-term survivors after allogeneic hematopoietic stem cell transplantation: retrospective analysis at a single institute. Biol Blood Marrow Transplant. 2017;23:2159-65.

49. Touzot M, Elie C, van Massenhove J, Maillard N, Buzyn A, Fakhouri F. Longterm renal function after allogenic haematopoietic stem cell transplantation in adult patients: a single-Centre study. Nephrol Dial Transplant. 2010;25: $624-7$.

\section{Publisher's Note}

Springer Nature remains neutral with regard to jurisdictional claims in published maps and institutional affiliations.

Ready to submit your research? Choose BMC and benefit from:

- fast, convenient online submission

- thorough peer review by experienced researchers in your field

- rapid publication on acceptance

- support for research data, including large and complex data types

- gold Open Access which fosters wider collaboration and increased citations

- maximum visibility for your research: over $100 \mathrm{M}$ website views per year

At BMC, research is always in progress.

Learn more biomedcentral.com/submissions 